\title{
Lessons Learned from Responsibility to Protect (R2P) in Libya
}

\author{
Fadhila Inas Pratiwi \\ University of Birmingham
}

\begin{abstract}
Responsibility to Protect $(\mathrm{R} 2 \mathrm{P})$ is an obligation on the part of the international community and on the part of the states to protect civilians from mass atrocities by doing several actions like giving international aids, reducing poverty, supporting peacebuilding, educating the population, until military intervention. However, military intervention under $\mathrm{R} 2 \mathrm{P}$ norm in Libya produce a counterproductive result which then led the country into civil war. From this background, therefore, the purpose of this article is to examine the implementation of $R_{2} P$ in Libya into four types of lessons learned. The first lesson, $R_{2} P$ is corrupted by great powers. The second lesson is the inconsistency practice from an $R_{2} P$ military intervention. The third lesson is diplomacy must be prioritized rather than military intervention. The last is the recommendation to implement Responsibility while Protecting (RWP) principle in the $R 2 P$ framework.
\end{abstract}

Keywords: Responsibility to Protect (R2P), Libya, Diplomacy, Military Intervention, Responsibility while Protecting (RWP).

Responsibility to Protect adalah kewajiban suatu negara sebagai bagian dari komunitasinternasionaluntukmelindungimanusia daripemusnahan massal dengan melakukan berbagai tindakan seperti memberi bantuan internasional, mengurangi kemiskinan, mendukung terciptanya perdamaian, mengedukasi populasi hingga melakukan intervensi militer. Namun, intervensi militer di bawah norma R2P di Libya tidak berhasil dan membawa Libya ke dalam perang sipil. Maka dari itu, tulisan ini bertujuan untuk menilai implementasi R2P di Libya ke dalam empat tipe pembelajaran. Pembelajaran pertama, $\mathrm{R}_{2} P$ diperburuk oleh negara berkekuatan besar. Pembelajaran kedua, intervensi militer di bawah norma R2P tidak konsisten. Pembelajaran ketiga, diplomasi harus diprioritaskan dibanding intervensi militer. Pembelajaran keempat adalah implementasi Responsibility while Protecting (RWP) dalam kerangka kerja R2P.

Kata-kata kunci: Responsibility to Protect (R2P), Libya, Diplomasi, Intervensi Militer, Responsibility while Protecting (RWP). 
Military intervention under R2P framework, being applied for the very first time in Libya in 2011 when Libya experiencing civil conflict between the government that ruled by Moammar Qaddhafi regime and the rebels and turns the country into chaos. As a newly acknowledged principled Responsibility to Protect (R2P) is about obligation on the part of the international community and obligation on the part of states to protect civilians from mass atrocities by doing several actions like giving international aids, reducing poverty, supporting peacebuilding, educating the population, until military intervention. Those actions can be done under the R2P norm. R2P has already been applied successfully in several countries, such as in Kenya and Cote d'Ivoire (The Brookings Institution 2014). However, in Libya, the discussions about R2P will raise questions on whether the act is successful or not, whether it is justifiable or not, and whether it is the right thing to do or not. Because the aftermath from the military intervention turns out make the country into a civil war and arguably did not reduce the conflict. This article addresses the lessons that have been learned about R2P in Libya in 2011. It starts by explaining $\mathrm{R} 2 \mathrm{P}$ and its implementation in Libya which ends up as a failure. Then, it elaborates further about the lessons learned from Libya, which is divided into four sections. The first section discussed the problem of R2P that corrupted by great powers that makes military intervention far from its mandate. The second is the inconsistency of $\mathrm{R} 2 \mathrm{P}$ approach which led to the question of credibility of military intervention in Libya along with another supporting examples such as Syria and Bahrain. The third is the suggestion to use diplomacy first rather than military intervention since that there is an R2P implementation that succeed without military intervention like in Kenya and Guinea. Finally, there is an explanation about responsibility while protecting as a new set of values for R2P framework.

\section{The Implementation of R2P in Libya}

$\mathrm{R} 2 \mathrm{P}$ is a new principle since 2001 when International Commission on Intervention and Sovereignty (ICISS) launch a report framework and coins the term Responsibility to Protect (R2P). This principle is used to stop genocide, war crimes, ethnic cleansing, and crimes against humanity (ICISS 2001,6). The works focuses on state sovereignty that has to be responsible for protecting people from those four crimes. Moreover, the implementation is not only to protect, but also to prevents, to react, and to rebuild. In addition to that, military intervention option will be used as the last tools to conduct the implementation (ICISS 2001, p. 9).

In Libya context, it started when the Arab Spring began in 2011, which gives an opportunity for the people to change their political regime from North Africa to the Middle East. In February 2011, the protest in Libya escalated quickly to civil war because Muammar Qaddafi as the president limits the rights of his citizens to protest and violates human rights by using terror against his oppositions, especially in the eastern Benghazi (Kuperman 2013, 107; Silander 2013, 269). This situation created responses in the form of United Nations Security Council resolutions number 1970 on February 26, 2011 and number 1973 on March 17, 2011 about arms embargo towards Libya, no-fly zone for Libya, and the authorization of the use of military force to protect the civilians (Bellamy and Williams 2012, 274; Gifkins 2016, 148-9). On March 19, 2011, two days after UN passed the second resolutions, North Atlantic Treaty Organization (NATO) led intervention in Libya. The action took thirty-six weeks to complete, which ended with the overthrown of Qaddafi regime. The action costs many lives as based on 
US data, the toll death is around 8,00o people, while according to Libya government, the total is 11,500 (Kuperman 2013, 122-3).

R2P in Libya soon turned into a disaster. NATO intervention went too far from its mandate by overthrowing Muammar Qaddafi regimes, then continued by giving military support to rebels who are also committing war crimes and violating human rights; and NATO just lets the rebels execute Qaddafi (Bachman 2015, 56; Bellamy 2014, 2). Soon, Libya fell into anarchy and divided by militants groups. There was no democracy and it started to become a failed state where state no longer can maintain a monopoly over the legitimate use of physical force within a given territory and over a given population (Hobson 2016, 435; Wolff 2011, 960). From the very first beginning, the intervention was intended to focus on regime change instead of to protect the civilians from mass atrocities. The situation became more hostile, there were military instability that led to civil war, and IMF and World Bank took control of the state's economy (O’shea 2012, 183).

\section{The first lesson learned: $R 2 P$ is corrupted by great powers}

Basically, R2P is aimed to redefine states' sovereignty that cannot be longer understood as unimpeachable or absolute control of a given territory. Instead, it should protect people's human rights inside the state territory from abusive government. Moreover, the notion sovereignty as responsibility implies that states have to protect and to be responsible for their citizens. When states are unable to defend, but rather harm their people, their sovereignty is temporarily suspended. Then, the R2P will move to the international community, and it is the right thing to do for other states to carry out the intervention (ICISS 2001, 13-7; Moses 2013, 116-8; Pattison 2010, 4). Historically, the increasing intervention on other states' problems will strengthen international human rights norms, enhance humanitarian intervention, and increase the impact on human security issues. Because it will imply that state authorities are responsible for the functions of protecting the safety and lives of citizens to the international community therefore it means that state are responsible for their action (Moses 2013).

However, not all good intentions will end up with good results. R2P in Libya is a total failure. The aftermath from R2P military intervention in Libya cannot prevent the escalation the local conflict between the regime and the opposition. The level of violence continues to increase and the country openly rejected to cooperate with international community (Berti 2014, 29-30). This is parallel with Realist view that most humanitarian intervention involves strong states interfering the weak, with less good intention, and that national interest will always be the ulterior motives of the action. Moses argues that R2P exercises sovereignty under international community, which is the justification of the norms will lack of form and clarity (Moses 2013, 126). Who have the rights to authorize the humanitarian intervention and what happens if the powerful state that carries out the intervention abuses their power and ignores the actual mandate. Based on realist view, the response is simply imperialism practice under humanity principle (Moses 2013, 130). R2P cannot be politically neutral. There are always preferences to pursue state's objective. The intervention also means taking sides in a conflict, which means there is no absolute innocent parties. The legitimation of using forces will produce violence and harm, and often leads towards bad results (Hobson 2016, 438; Moses 2013, 134). 
R2P in Libya is the first time in history that coercive methods are used under R2P framework and are approved by the members of Security Council, even when China and Russia was abstain from the vote (Morris 2013, 1271; Paris 2014, 569). The intervention was conducted mostly by the strong states like France, United Kingdom, and the United States. However, the reasons behind this intervention are still questioned because thinking that it is purely conducted to safe human lives seems impossible. In fact, after the end of cold war, operations under humanitarian intervention name were often blurred with self-interest, the pursuit of power, and even geo-strategic interests. Moreover, military intervention is costly and dangerous, and even when the states willing to help other countries, they have to think about their people too (Paris 2014, 573-4).

At first in Libya, responsibility to protect is a key element in delivering international intervention to stop the on-going mass atrocities. The resolutions adopted by the UNSC on Libya is validating that notion. The first UNSC resolution in 26 February 2011 calling on the government of Libya to meet its responsibility to protect its population and the same with the next UNSC resolution 1973 on 17 March 2011 asking Libya again to ensure the protection of civilians. It also can be argued that intervention under $\mathrm{R} 2 \mathrm{P}$ operation is happened because Libya government failed to meet its obligation, and therefore international community have to take action to prevent further mass atrocities in Libya (Berti 2014, 25-26). However, even if the action is solely grounded from R2P framework, but the reality shows that there is state interest within military intervention in Libya. It can be seen when the intervention exceeding the original mandate from protecting civilians become a regime change. NATO led intervention decided to support the Libyan opposition forces, including expanding the scope of bombing campaign and targeting Libyan military assets. NATO seems to be more aggressive interpreting the UN Resolution 1973 which led to its violation. The example of this is by giving military aids to the regime opposition with 20.000 tons of weapons and deployment ground forces to strengthen their capabilities. This again questioning whether the R2P in Libya intend to protect the civilians or fighting Qaddafi's military. Libyan leader was found in convoy vehicles and NATO aircraft fired the convoy and stopping it. Then the rebels captured Qaddafi and killed him, after that NATO announce the end of the intervention (Paris 2014, 581-2).

\section{The second lesson learned: $R 2 P$ is consistent with inconsistency}

The next lessons learned from R2P in Libya is inconsistency. The intervention is morally problematic because NATO-led coalition has failed to response similar situations like in Bahrain, Syria, and Yemen. Inaction towards those states shows different moral standards on where they should intervene. It is morally wrong when there are humanitarian crisis in several locations, but the R2P principles are not applied on them (Nuruzzaman 2013, 63; Pattison 2010, 276). Even if there are several arguments like not everybody can be protected and that it is costly and expensive. Another argument would be normative principles like R2P do not exist in vacuum condition and do not provide guidance on how to respond to the crisis; and also that decision makers need to exercise their judgment on each case basis (Bellamy, n.d., 8-9). Still, it shows the double standards that the norms should be applied for all, and this is will lead to the assumptions that military intervention in Libya violates the R2P norm (Nuruzzaman 2013, 57; Paris 2014, 588). 
Different from Libya, the Security Council failed to act on Syria because China and Russia used their vetoes. Notably, both countries have strategic and commercial interest in Syria (Nuruzzaman 2013, 65). Civil war in Syria already happened since 2011, more than 400.000 people died, 6.1 million people internally displaced and more than four million people have been displaced as refugees in the neighbouring countries (Human Rights Watch 2017). Syrian's civilians trapped inside their country where their government and armed rebel against each other. While there also the emergence of Islamic State of Iraq and Syria (ISIS) who threatened Syrian people lives. After China and Russia vetoed UN resolution in 2012 which resulted military inaction from international community there was a significant increase in the killing rate. Between February and November in 2012 the total death rocketed from 5.000 people to around 60.000 people. UN Security Council failed in protecting Syrian people. Because of the inaction, makes Syria become the world's worst case of ongoing mass atrocities, civilian displacement and humanitarian catastrophe (Adams 2015, 5). This case leads to criticism towards R2P, suggesting that the norms discriminate between rich, poor, weak, and powerful state.

Besides Syria, the inconsistency in applying R2P norms also happens in Bahrain. Since 2011, Bahrain has been experiencing brutal repression and torture from its government. External military intervention, state-sponsored sectarianism, and institutionalized corruption also exist. However, the R2P action in this situation is notably small. There is no single resolutions to discuss the crisis in Bahrain since it happens, and UNSC response is also unseen (Hehir 2015, 1136). The opposite happened in Libya as after the crisis began in February 2011, the UNSC passed the 1973 resolutions on March 17, 2011, only a few weeks after the conflict arises. This is then questioned the credibility of the military intervention itself. Intervention in Libya was highly imperfect, and the intervention highlighted the fact that there is a lot of work need to be done with regards to R2P and the nature, limits, and legitimacy of military intervention. Because of this imperfection, make the intervention in Libya become a disaster, the country right now experiencing the civil war which proves as the counterreaction from the intention of military intervention under R2P norm. It also leads to the question, why it happens in Libya but not in Syria or Bahrain. The answer could be that the major powers have a collective interest which would lead to the ambiguous parameters in the operational of the military intervention itself. UNSC Resolution 1973 for example, lacked the clarity that needed to carry out an intervention at what extend it need to be done. It cost UN credibility when it comes to the enforcement of the principle that not applied for all. The credibility of both $\mathrm{R} 2 \mathrm{P}$ and the role of the UN as guarantor of international peace and security has been severely damaged in this case (Kersavage 2014, 32-33).

The result of the inconsistency in applying R2P arguably damage the norms itself. This is because in applying R2P norm there will be always the involvement from great powers that able to influence the decision to take military intervention in other states which experiencing mass atrocities. Geopolitics rivalry between great powers can be used to explained why military intervention in Syria under R2P norms did not happened in the very first place where in Syria thousands of people already died (Nikoghosyan 2017). While the military intervention in Libya also ignore the responsibility to protect the Libyan people. As James Pattison argued, "states are seemingly reluctant to accept this responsibility for fear of being obliged to act robustly in response to similar cases (Pattison 2011)." Moreover, R2P right now seen as the same with the humanitarian intervention and it can be argued that the norms served as a legal basis to do intervention 
to the other sovereign states regardless its initial purpose to save and protect civilians from mass atrocities (Pattison 2011). States might be easier to justify their military intervention towards other states by using R2P norms like Russia did. Putin justifying his action towards Georgia in 2008 and the annexation in Crimea in 2014 as forms of R2P (Kersten 2015). The use of military intervention in Libya and inaction in Syria and Bahrain confusing the application of the norms itself. Which makes the states have more leverage and opportunity to do what they want by disturbing other states sovereignty under R2P framework. Besides, the inaction of international community when there is a state experiencing mass atrocities even prove that the application of R2P norms still lack of consistency.

\section{The third lesson learned: Diplomacy must be prioritized rather than military intervention}

Another key point from Libya intervention is about military tools. Military action does not need to be used in R2P. The action was taken without considering the responsibility of its outcomes (Chandler, 2). Meanwhile, the third pillar of R2P state several other ways to protect populations (International Coalition for The Responsibility to Protect 2013, 20). Because using military force will mislead the core values of R2P. On April 11, Qaddafi accepted African Union proposal to a cease-fire and conducted a national dialogue with the rebels. Good intention from Qaddafi was also shown on May 26 when he offers negotiations to constitutional government and give the compensation for the victims. However, the rebels rejected both of Qaddafi's ideas, and NATO, as the third party, did not acknowledge Libya government's effort to pursue diplomatic solutions and instead, they helped the rebels to overthrow Qaddafi (Kuperman 2013, 155). It shows that military forces in Libya closed further possibilities to proceed peaceful negotiation between the government and the rebels and even made the condition worse.

Based on R2P principle, military intervention must be used as the last resort if diplomacy has failed or it will bring minimum harm to the people and lead to the success result. However, if not war, what need to be done. Economic sanctions probably can be served as one of the answer. In fact, economic sanctions are not make the situation getting better and even can cause harm like the war did and the effectiveness of it still debatable. For instance, sanctions against Iraq in 1990 s brought the country into famine, high rates child mortality, malnutrition, shortage of medical supplies and clean water (Pattison 2015, 396). Therefore, this make another alternative more preferable that is diplomacy. Diplomacy efforts can be included in the preventive measures in a sense that it can help to prevent the conflict occurs or reduce the possibility of the escalation. Supporting by Welsh argument that prevention can have two functions. Those are for long-term structural assistance and for short-term to prevent future mass atrocities that might be happened. Basically, these two functions have the same logic that prevention is both possible, prevention does not mean that there will be no violence, although violence still unavoidable. However, the prevention is more favourable reaction to the international peace and security rather than post-conflict reaction (Welsh 2016, 217). 
Like what happen in Kenya is one of the R2P actions with satisfactory results without military intervention. On December 27, 2007, Kenya had a dispute with the national election, which led to the humanitarian crisis. This crisis cost 1,00o lives and forced hundreds of thousands of people to flee from their homes, bringing economic instability to the country (Sharma and Welsh 2015,2 ). The violence did not stop. Within three days, 164 people were killed and within three weeks, five hundred people died. This situation called mediator to come to Kenya to conduct preventive diplomacy, Kofi Annan (former UN Secretary General), Graca Machel (Mozambican politician and humanitarian), Benjamin Mkapa (former President of Tanzania). The mediators' agenda was to stop the violence, to restore fundamental human rights, to address the humanitarian crisis and promote reconciliation, to overcome political crisis, and to develop longer-term strategies for durable peace. The negotiation took up to forty-one days, and the last session of mediation involved five-hour marathon talks between the leaders of conflicting parties and chaired by Annan who determined not leave without an agreement. Finally, the disputing parties agreed to sign the agreement and to stop the violence (Sharma and Welsh 2015, 7-8).

Beside Kenya, there also Guinea conflict between 2009-2010, where preventive measure leads a success results. In September 2009, government forces killed 156 demonstrator and UN Commission regard that the situation as a crime against humanity. However, after the incident surprisingly in November 2010, the situation not getting worse and not became an ethnic conflict when presidential election takes place. This is because there was preventive action that done by Special Representative of the Secretary General that cooperate with officials from Economic Community of West African States (ECOWAS). They were struggling to apply preventive diplomacy, arms embargos, travel bans, and give threats of International Criminal Courts (ICC) prosecutions. Both Kenya and Guinea show that non-military intervention could possibly lead to the conflict resolution. The mechanism is still largely controlled by UN Secretariat, within R2P framework, and cooperate with the regional actor. Mediator also played an important role in both cases. Since that they were truly dedicated in pursuing the agreement in order to end the conflict. Although the violence is inevitable in both cases. However, the preventive measure that done by the mediator, makes the conflict not became a bloody civil war and even an effective tool to end the conflicts (Welsh 2016, 221-222). It cannot be denied that the involvement of great powers has significant impact on the application of R2P. Although the case in Kenya or Guinea are simpler than the one in Libya with great powers involvement, but still the main ideas to used diplomacy first and military intervention as the last resort applied successfully in both cases. As previously stated that the military intervention closed the possibility to have peaceful conflict resolutions have to be take into account seriously.

\section{The fourth lesson learned: Being responsible while protecting}

Responsibility While Protecting (RWP) has to be taken into considerations. This Brazil's idea is aimed to make the decision-making process by the Security Council more transparent, accountable, and focus on prevention (Bellamy 2014, 1). There are at least three purposes of the RwP: 1) prioritising the use of non-coercive means in exercising R2P norms. This is because military intervention tends to bring more harms than good and must be used when political and diplomatic strategies had failed; 2) it brings more considerations regarding the specific criteria when the decision of military 
intervention comes to the table; 3 ) it echoed the problem of the aftermath from the military intervention that still inadequate in managing the crisis (Tourinho et al. 2016, 138). This is in parallel with South African President, Jacob Zuma opinion, although he voted in favour for 1973 resolution. However, he later criticized the NATO intervention in Libya that violated its original mandate and failed to support the African Union Roadmap for Peace proposal for Libya (Bellamy 2014, 5).

Furthermore, RWP is a necessary tool to prevent cases similar to Libya. There are three pillars of R2P: the first protection responsibilities of the states, the second international assistance and capacity building, and the third timely and decisive response (ICRtoP 2013, 20). These three pillars work together and support each other. However, the RWP suggests that the three pillars must work in sequence and not directly conduct military action like in pillar three. Although at the end military intervention can be a choice, this has to be guided by criteria, cautious, and through thorough decision making have to be done on a case by case basis. In addition, RWP seeks accountability mechanism to monitor how the resolutions are interpreted and implemented. It also ensures the transparency the military operations under R2P and the accountability for the one who conducts the action (Tourinho et al. 2015, 146). This Brazilian contribution widely accepted since that it improves the strength of R2P norms and more consideration when taking military intervention decision has been extensively promoted (Pattison 2015, 940).

Preventive and non-coercive means needs to be pursued first because it will reduce the risk of armed conflict. Although it is complicated when applied it in the local conflict situation but it still worth to try to reduce the possibilities of mass atrocities that might sooner happened. By giving foreign aid can be used as tools to pursue peace negotiations, giving some incentives to the conflicting parties for engagement in mediation efforts, and limit the opportunity for those who likely to do mass atrocity crimes. Along with the cooperation with other institutions such as Peacebuilding Commission, UN Peacekeeper can be served as the third party that capable to mediate the negotiation process and make the preventive measures more effective (Bellamy 2014, 7-8; Tourinho et al. 2015, 144). After all, RwP value gives contributions towards R2P norms by opening up more considerations that as states they have to think several times before making the decision to do military intervention. Since that they have to be responsible for the outcomes and aftermath from their decision as well. Which also in parallel with the R2P norms, that are not only to react, but also to prevent and to rebuild the conflicting states.

\section{Conclusion}

To summarise, there are four aspects that can be learned from the failure of R2P practice in Libya. The first is the concept of sovereignty as a responsibility that is not well conceptualized in this case. The motives of countries involved in military intervention in Libya, such as France, the UK, and the US, are questioned on whether they purely intend to save lives or to pursue their self-interest as their action in Libya exceeded the original mandate by overthrowing the Qaddafi regime.

Second, R2P norms were not applied for all, the inaction in Syria and Bahrain, would lead to the question what is the credibility of the military intervention in Libya itself. 
Because of it lacks the clarity and operational procedure, it can lead to the assumptions that the failure in Libya proves the counterreaction of military intervention under R2P norm.

The third is about the use of the military instrument as tools to enforce R2P values. Military intervention is not a good option because it will close the possibilities to do diplomatic action. Besides, the military attack will always unintendedly take civilians' lives, which also violates human rights. Using diplomacy would be the favourable option to end the conflict in a peaceful way, like what happened in Kenya and Guinea. Although both cases are much simpler than the one in Libya without much great powers involvement, as applying R2P norms they should be considering the use of military intervention as the last resort.

The fourth is adding the value of Responsibility while Protecting. When several countries decide to intervene, they have to think about how the procedure will be conducted, what will be the results, and whether it is good or bad. This also puts emphasis on transparency, accountability, and prevention as these criteria are important for the intervening states. It also become a guidance to conduct an intervention with favourable results and a higher probability of success.

\section{References}

\section{Books}

Bellamy, Alex J, 2014. The Responsibility to Protect: A Defense. [E-book] Oxford: Oxford Scholarship Online. Available at: http://www.oxfordscholarship.com/ view/10.1093/acprof:0so/9780198704119.001.0001/acprof-9780198704119 [Accessed 20 November 2016].

Pattison, James, 2010. "Humanitarian Intervention and The Responsibility to Protect: Who Should Intervene?”. [e-book] Oxford: Oxford Scholarship Online. Available at: http://www.oxfordscholarship.com/view/10.1093/ acprof:oso/9780199561049.001.0001/acprof-9780199561049 [Accessed 18 November 2016].

Sharma, Serena K\&Welsh,Jennifer M, 2015. The Responsibility toPrevent:Overcoming the Challanges of Atrocity Prevention. [E-book] Oxford : Oxford University Press Scholarship Online. Available at : http://www.oxfordscholarship.com/ view/10.1093/acprof:0so/9780198717782.001.0001/acprof-9780198717782 [Accessed 18 November 2016].

\section{Briefing Paper}

Adams, Simon, 2015. Failure to Protect: Syria and the UN Security Council. The Global Centre for the Responsibility to Protect. Occasional Paper Series No. 5.

International Commission on Intervention and State Sovereignty, 2001. The Responsibility to Protect. Ottawa: International Development Research Centre

International Coalition for The Responsibility to Protect, 2013. A Toolkit on The Responsibility to Protect [pdf]. Available at: http://www.responsibilitytoprotect. org/ICRtoP\%20Toolkit\%20on\%20the\%20Responsibility\%20to\%20Protect(1). 
pdf [Accessed 18 November 2016].

The Brookings Institution, 2014. The Responsibility to Protect Hangs In the Balance

[Online]. Available at: http://www.responsibilitytoprotect.org/index.php/ component/content/article/35-r2pcs-topics/5320-brookings-institute-theresponsibility-to-protect-hangs-in-the-balance [Accessed 18 November 2016].

\section{Journals}

Bachman, Jeffrey, 2015. "R2P's "Ulterior Motive Exemption" and the Failure to Protect in Libya". Politics and Governance, 3 (4), pp. 56-67.

Bellamy, Alex J \& Williams, Paul D, 2012. "Principles, Politics, and Prudence: Libya, the Responsibility to Protect and the Use of Military Force". Global Governance, 18 (3), pp. 273-297.

Berti, B, 2014. "Forcible intervention in Libya: revamping the "politics of human protection"?". Global Change, Peace \& Security, 26 (1), 21-39.

Chandler, David, 2015. “The R2P Is Dead, Long Live the R2P: The Successful Separation of Military Intervention from the Responsibility to Protect”. International Peacekeeping, 22 (1), pp. 1-5.

Gifkins, Jess, 2016. "R2P in the UN Security Council: Darfur, Libya and beyond". Cooperation and Conflict, 51 (2), pp. 148-165.

Hehir, Aidan, 2015. "Bahrain: an R2P Blind Spot?". The International Journal of Human Rights, 19 (8), pp. 1129-1147.

Hobson, Christopher, 2016. "Responding to Failure: The Responsibility to Protect after Libya”. Millennium: Journal of International Studies, 44 (3), pp. 433-454.

Kersavage, K, 2014. "The "responsibility to protect" our answer to "never again"? Libya, Syria and a critical analysis of R2P". International Affairs Forum, 5 (1), 23-41.

Kuperman, Alan J, 2013. "A Model Humanitarian Intervention? Reassessing NATO's Libya Campaign”. International Security, 38 (1), pp. 105-136.

Morris, Justin, 2013. "Libya and Syria: R2P and the spectre of the swinging pendulum." International Affairs, 89 (5), pp. 1265-1283.

Moses, Jeremy, 2013. "Sovereignty as irresponsibility? A Realist critique of the Responsibility to Protect". Review of International Studies, 39 (1), pp. 113-135.

Nikoghosyan, Hovhannes, 2017. "Great Power Interventions and the Future of Responsibility to Protect” [online]. Russia in Global Affairs. Available at: http:// eng.globalaffairs.ru/valday/Great-Power-Interventions-and-the-Future-ofResponsibility-to-Protect-18989 [Accessed 13 November 2017]

Nuruzzaman, Mohammed, 2013. "The "Responsibility to Protect" Doctrine: Revived in Libya, Buried in Syria”. Insight Turkey, 15 (2), pp. 57-66.

O'shea, Elizabeth, 2012. "Responsibility to Protect (R2P) in Libya: Ghosts of the Past Haunting the Future”. International Human Rights Law Review, 1 (1), pp. 173-190.

Paris, Roland, 2014. "The 'Responsibility to Protect' and the Structural Problems of Preventive Humanitarian Intervention”. International Peacekeeping, 21 (5), pp. 569-603.

Pattison, James, 2015. "The ethics of diplomatic criticism: The Responsibility to Protect, Just War Theory and Presumptive Last Resort”. European Journal of International Relations, 21 (4), pp. 935-957.

Silander, Daniel, 2013. "R2P-Principle and Practice? The UNSC on Libya". Journal of Applied Security Research, 8 (2), pp. 262-284.

Tourinho, Marcos., Stuenkel, Oliver., \& Brockmeier, Sarah, 2015. "Responsibility while 
Protecting: Reforming Implementation”. Global Society, 30 (1), pp. 134-150.

Welsh, Jennifer, 2016. "The responsibility to prevent: Assessing the gap between rhetoric and reality". Cooperation and Conflict, 51 (2), pp. 216- 232.

Wolff, S., 2011. "The regional dimensions of state failure". Review of International Studies, 37 (3), pp. 951-972.

\section{Internet}

Human Rights Watch, 2017. Syria Events 2016 [online]. Available at: https://www. hrw.org/world-report/2017/country-chapters/syria [Accessed 19 October 2017].

Kersten, Mark, 2015. The Responsibility to Protect doctrine is faltering. Here's why [online]. Available at: https://www.washingtonpost.com/news/monkeycage/wp/2015/12/o8/the-responsibility-to-protect-doctrine-is-failing-hereswhy/?utm_term=.4c4fe79d67ed [Accessed 19 October 2017].

Pattison, James, 2011. Roundtable: Libya, RtoP, and Humanitarian Intervention [online]. Available at: https://www.thefreelibrary.com/ Introduction.-a0271594905 [Accessed 19 October 2017]. 